\title{
COVID-19 PANDEMIC AND HUMAN RESOURCE DEVELOPMENT PRACTICE IN NEPALESE COMMERCIAL BANKS
}

\author{
Manoj Kumar Chaudhary, Ph.D \\ Associate Professor \\ Center Department of Management, \\ Tribhuvan University, Kathmandu, Nepal \\ Ajay Prasad Dhakal \\ Associate Professor \\ Center Department of Management, \\ Tribhuvan University, Kathmandu, Nepal
}

\begin{abstract}
A leadership style and its practice can be considered as the foundation of overall nations development. So, this paper majorly aims to explore the leadership style among academic leaders in his/her education sectors in overall. For this, a semi-structured interview questionnaire was applied to investigate and obtained opinion from the respondents. The results of this study exposed that extraordinary collaboration, responsibility, correspondence, and nurturing and strengthening are the major things that leads to the efficient academic operations. Thus, the paper concludes that academics of Nepal were favor of five leadership methods besides the task-oriented authority in Nepalese context. Finally, the finding of this research would anticipate a more extensive sense of direction towards successful academic's sectors operations.
\end{abstract}

Keywords: Leadership Style, Social Development, Efficient Operations, Higher Education, Nepal.

\section{Introduction}

Human Resource holds a key position for the sustainable development of an organization. Hence, it is an utmost obligation of an organization to ensure the development of human capital. Armstrong (2014) recited human resource development as distinctive practice which shapes the core competencies that determine how firms compete. Human Resource Development is a procedure of creating and/or potentially releasing skills through organizational development (OD) and workforce preparing and advancement for the sake of improving delegation (Swanson, 2001). It is an orderly cycle pointed toward improving capabilities of the individual and workforce bureau through training and advancement, development of career, and authoritative advancement practices to accomplish unrivaled execution of work (Garavan, 2007; Nadler, 2012). Furthermore, the basic purpose of HRD is to improve and develop employee competencies to enhance the quality of HR culture in an organization. It is a requirement of organizations to implement different human resource development strategies to develop their workforce to ensure efficiency in operation (Potnuru\& Sahoo, 2016).HRD is a methodology established on the conviction that individuals are equipped for development - given an atmosphere that encourages personal development. Development is, in this way, significant for an association. HRD needs to enhance the ability of its HR to ensure sustainability in skill, maturity, competence, self-awareness, adjustment to the environment, and confidence (Dayal, 1993). The organizational adequacy lies in human resource quality and human resource development planning to improve representatives' abilities (Kareem and Hussein, 2019). Nadler (1969) introduced the concept of human resource development through 
his participation in the Miami conference of the American society of training and development. Nadler (1969) found that many scholars and researchers had entered the HRD field and the definition regarding the subject needs to be propounded. Human resource development is a process of developing and enhancing the skills of an employee. The reason for it is to improve singular, group, work measure, and the firm's framework mechanism (Swanson \& Elwood,2009). McLagan and Suhadolnik (1989) define HRD as the integration of training and development, career development, organizational development to improve individual,group, and organizational results. Moreover McLagan and Suhadolnik (1989) characterize HRD as the reconciliation of related practices, which include learning and advancement, profession advancement, and corporal advancement to improve the individual and team information, abilities and capacities to upgrade authoritative results. Moreover, successful HRD norms feature the lean association, capacity and adaptability of the HR group, at the correct time (Mittal, 2013). As HR improvement presumes the idea of regarding people as an extraordinary resource of the association, it definitely adds to the accomplishment of organizational objectives (Wilson, 2005). Redman and Wilkinson (2006), recommended that human resource development is concerned with creating human skills all through time-bound and arranged learning practice to improve the inventive contribution of individuals to accomplish hierarchical objectives.

The embodiment of an improved HR comes from the degree of responsibility depicted by an individual worker. Responsibility is considered as a strength that ties an individual worker to an executive-plan that is of importance to a specific undertaking (Meyer and Herscovitch, 2001). Responsibility is characterized as one's inspiration to work in a specific job or as a demonstration of obligation to trust or promise to a person or thing
(Corridor, 1976). The idea of hierarchical responsibility has received a major consideration from many researchers throughout the years. Porter (1974) had explained association responsibility as the measure of feelings and empathy people have toward their association. Organizational responsibility is the relative strength of a person's recognition and association in a specific organization (Porter, Crampon and Smith, 1976; Steer, 1977).It is an inclination of devotion to one's employer association, readiness to labor for that senior personnel, and the aim to stay with that association (Meyer \& Allen, 1988). Training and advancement exercises are significant HR capacities answerable for sharing information and abilities for a specific work (Khan, 2013). A career is a developing succession of an individual's work encounters over the long run. It identifies with the person's apparent arrangement of business, job that the individual acquires over the long run (Solomon, Bishop \& Dresser, 1986). Poon (2004) portrayed career responsibility as a predication on target profession accomplishment in the form of pay level and subjective professional achievement as career fulfillment. To pull in, create and hold the workers in the association, professional advancement is an essential thing (Frederick, 2014). Deloitte (2017) expounded that broad improvement openings lessens worker turnover rate. Continuation responsibilities are the necessities of people for the constant work of the association (Allen and Meyer, 1991), such responsibilities are for the most part dependent on advantages. As per (Baker, 1960), continuance responsibility is impacted by age and length of administration (Aranya \& Jacobson 1975; Ferris and Aranya 1983; Parasuraman \& Alutto 1984; Stevens et al. 1978). At the point when representatives are more satisfied with their work, it implies that the higher the worker's departure cost, the employee will give a commitment of continuation and keep on working in the association. 
The covid-19 pandemic has created severe impact on many financial and non-financial institutions. Many banks and financial institutions have cut off their numbers of employees and operated with limited numbers of employees. Many Nepalese banks have used work from home policy during covid-19 pandemic. It is seen the importance of human resource development practices has been highly valued during the pandemic to carry out the banking operations efficiently and effectively during the pandemic. Hence, this study has aimed to explore the contribution of HRD practices in the employee's commitment in Nepalese commercial banks.

\section{Methodology}

This research has suggested descriptive and explanatory research planning to analyze the effect of human resource development on workers' dedication in Nepalese commercial banks. To satisfy the expressed goals, 350 organized survey questions (in light of five-point Likert scale ranging from strongly agree- 5 to strongly disagree1) have been circulated to workers of various branches of 27 business banks operating in Nepal; out of which 290 usable responses of poll has been utilized for information investigation. The investigation has utilized a purposive sampling procedure to choose the sample for the research. The gathered information is prepared through Msexcel and SPSS v23.Descriptive statistics; correlation, frequency tables and percentage analysis are utilized for data presentation and Cronbach's Alpha for all the things have been utilized for reliability tests. The estimations of Cronbach's Alpha are introduced in table 1.

Table 1: Reliability Statistics

\begin{tabular}{|c|c|}
\hline Statements & Cronbach's Alpha \\
\hline Training and development opportunity & 0.872 \\
\hline Career growth opportunity & 0.933 \\
\hline Use of existing skills & 0.726 \\
\hline Employees' commitment & 0.804 \\
\hline
\end{tabular}

Source: SPSS output

The Cronbach's alpha of Training and development opportunity related items is 0.872 , career growth opportunity related items are 0.933 , use of existing skill related items is 0.726 and employees' commitment related items is 0.804 . The value of Cronbach's Alpha of all the constructs used in the study is more than 0.7, As a general rule, a coefficient greater or equal to 0.70 is considered acceptable and a good indication of construct reliability (Nunnally, 1978). The obtained values of Alpha are greater than 0.70, which indicated that all items related to construct are reliable and acceptable.

Table 2: Respondents Profile

\begin{tabular}{|l|l|l|l|l|l|l|}
\hline \multirow{2}{*}{ Academic Qualification } & \multicolumn{3}{|l|}{ Gender of the Respondents } & \multirow{2}{*}{ Total } & \multirow{2}{*}{} \\
\cline { 2 - 5 } & Male & $\%$ & Female & $\%$ & & \\
\hline Above Master Degree & 21 & 7.24 & 12 & 4.14 & 33 & 11.38 \\
\hline Master Degree & 80 & 27.59 & 28 & 9.65 & 108 & 37.24 \\
\hline Bachelor Degree & 46 & 15.86 & 60 & 20.70 & 106 & 36.56 \\
\hline Below Bachelor Degree & 13 & 4.48 & 30 & 10.34 & 43 & 14.82 \\
\hline
\end{tabular}




\begin{tabular}{|l|l|l|l|l|l|l|}
\hline Total & 160 & 55.17 & 130 & 44.83 & 290 & 100 \\
\hline
\end{tabular}

\section{Source: Survey, 2020}

Table 2 shows that $55 \%$ respondents are the male and about $45 \%$ respondents are the female. Table also shows that $7.24 \%$ respondents having above master degree qualification are male and only $4.14 \%$ female respondents are having above master degree qualification. Table displays that $37.24 \%$ respondents are having master degree qualification among them $27.59 \%$ are male and $9.65 \%$ are female respondents. Nearly $37 \%$ respondents are having bachelor degrees out of which $15.86 \%$ are male and $20.70 \%$ respondents are female. About $15 \%$ of respondents consisting below bachelor degree among that $4.48 \%$ are male and $10.34 \%$ are female. This table indicates that the majority of female respondents are having bachelor degrees whereas the majority of male respondents are having master degree academic qualifications. The data also convey that academic qualification of male staffs in banking institutions of Nepal is comparatively higher than the academic qualification of female staffs.

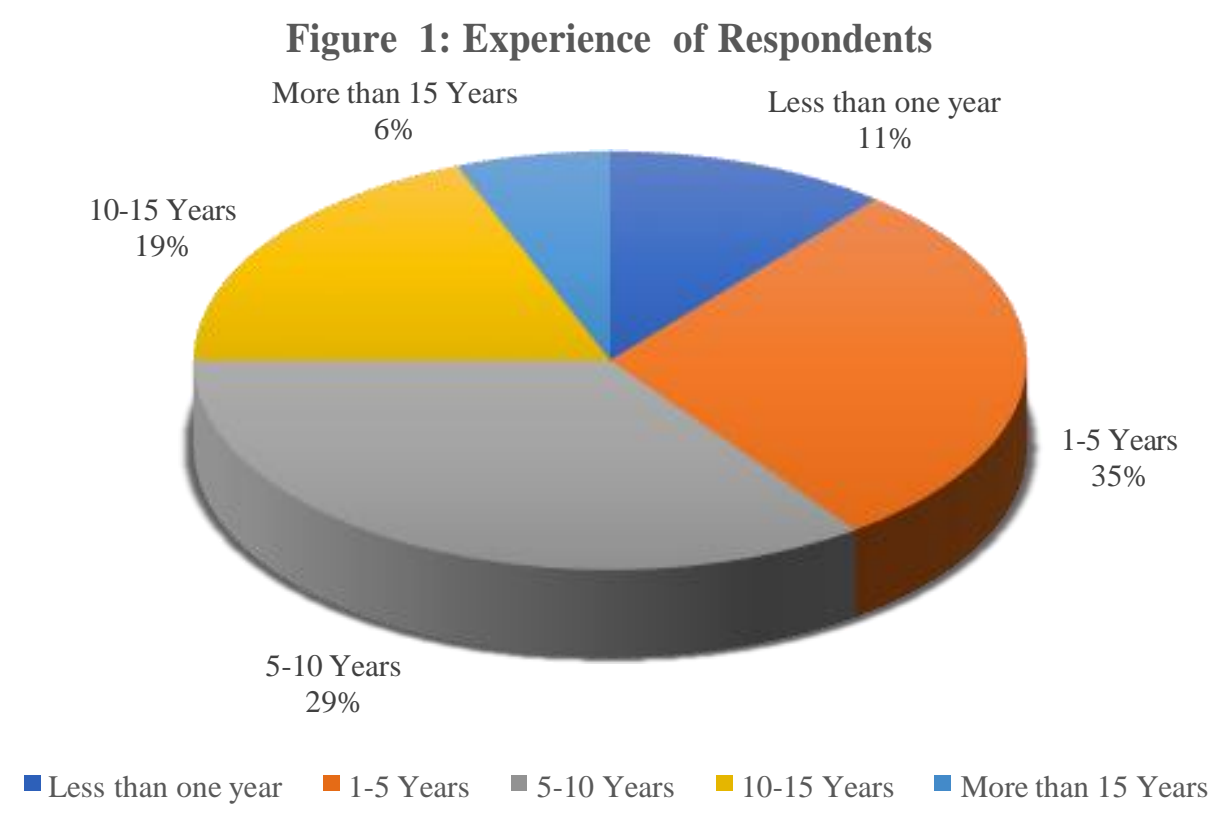

Source: Survey, 2020

Figure 1 shows the experience of respondent banking staff in their particular banks. It shows that $11 \%$ respondents have less than one year of experience, $35 \%$ respondents have $1-5$ years of experience, $29 \%$ respondents have 5-10 years of experience, $19 \%$ respondents have 10-15 years of experience and only $6 \%$ respondents have more than 15 years of experience in their working commercial banks. Figure shows that the respondents' percentage of higher years' experience in the same bank decreased which indicated that banking staff has shifted from one bank to another bank after having few years of experience for the higher-level posts in another bank. 
Table 3: Correlation between HRD variables and Employees' Commitment

\begin{tabular}{|c|c|c|c|c|}
\hline Variables & $\begin{array}{c}\text { Training and } \\
\text { development } \\
\text { opportunity }\end{array}$ & $\begin{array}{c}\text { Career growth } \\
\text { opportunity }\end{array}$ & $\begin{array}{c}\text { Use of } \\
\text { existing skills }\end{array}$ & $\begin{array}{c}\text { Employees' } \\
\text { commitment }\end{array}$ \\
\hline $\begin{array}{c}\text { Training and development } \\
\text { opportunity }\end{array}$ & 1 & & & \\
\hline Career growth opportunity & .29 & 1 & 1 & \\
\hline Use of existing skills & .23 & .19 & $.68^{* *}$ & 1 \\
\hline Employees' commitment & $.73^{* *}$ & $.76^{* *}$ & \\
\hline
\end{tabular}

Source: SPSS Output

Note:

** Correlation is significant at the 0.01 level (2- tailed)

The study in table shows that all the predictor variables were shown to have a positive association between them at a significant level of 0.01 and hence included in analysis. There is a positive relationship between the independent and the dependent variables.

The correlation between training and development opportunity and employees' commitment is 0.73 .
The correlation between career growth opportunity and employees' commitment is 0.76. Similarly, the correlation between use of existing skills and employees' commitment is 0.68 . The result of the table indicated that there is a positive relation between the attributes of HRD and employees' commitment to the Nepalese commercial banks.

Table 4: Summary of Regression model

\begin{tabular}{|c|c|c|c|c|c|c|}
\hline \multirow{3}{*}{ Model } & & $\mathrm{R}$ & R Square & Adjusted R & \multicolumn{2}{|c|}{ Std. Error of the Estimate } \\
\hline & & $0.849^{\mathrm{a}}$ & .760 & 0.745 & \multicolumn{2}{|c|}{1.12426} \\
\hline & & Sum of Squares & Df & Mean Square & $\mathrm{F}$ & Sig. \\
\hline \multirow{3}{*}{1} & Regression & 204.537 & 1 & 202.537 & 156.15 & 0.000 \\
\hline & Residual & 55.868 & 41 & 1.225 & & \\
\hline & Total & 260.405 & 42 & & & \\
\hline
\end{tabular}

a. Dependent variable: Employees' Commitment

b. Predictors: Constant, Training and development opportunity, Career growth opportunity, Use of existing skills.

The study used F-statistics to establish the appropriateness of the regression model to give reliable results. An F- significance value of $\mathrm{p}=0.000$ was established. This shows that the regression model has a less than 0.001 likelihood (probability) of giving a wrong prediction.

The table shows that the value of coefficient of determination (adjusted $\mathrm{R}$ square) is 0.745 for all the variables studied (Training and development opportunity, Career growth opportunity and Use of existing skills). This implies that there was a variation of $74.5 \%$ between the independent variable (Training and development opportunity, Career growth opportunity and Use of existing skills) and dependent variable (employees' commitment in Nepalese commercial banks). 
Thus, it means that training and development opportunity, career growth opportunity and use of existing skills explained $74.5 \%$ of employees' commitment in Nepalese commercial banks.

Table 5: Regression Coefficients

\begin{tabular}{|c|c|c|c|c|c|c|}
\hline \multirow{2}{*}{\multicolumn{2}{|c|}{ Model }} & \multicolumn{2}{|c|}{$\begin{array}{c}\text { Unstandardized } \\
\text { Coefficients }\end{array}$} & \multirow{2}{*}{\begin{tabular}{|c} 
Standardized \\
Coefficients
\end{tabular}} & \multirow[t]{2}{*}{$\mathrm{T}$} & \multirow[t]{2}{*}{ Sig. } \\
\hline & & B & Std. Error & & & \\
\hline \multirow[t]{4}{*}{1} & (Constant) & 15.684 & 1.634 & & 6.143 & 0.000 \\
\hline & $\begin{array}{l}\text { Training and } \\
\text { development } \\
\text { opportunity }\end{array}$ & 0.403 & 0.36 & 0.614 & 11.626 & .010 \\
\hline & $\begin{array}{l}\text { Career growth } \\
\text { opportunity }\end{array}$ & 0.476 & 0.105 & 0.006 & 0.109 & 0.021 \\
\hline & Use of existing skills & 0.376 & 0.023 & 0.163 & 0.125 & 0.036 \\
\hline
\end{tabular}

a. Dependent Variable: Employees' Commitment.

The results table 4 shows that a positive relationship exists between human resource development (HRD) and employees' commitment in Nepalese commercial banks. The unstandardized regression coefficients show how every metric unit changes in the independent variable, the dependent variable changes by $\mathrm{x}$ units. This implies that a unit increase in training \& development opportunity would lead to a unit increase in employees' commitment in Nepalese commercial banks at a factor of 0.403. A unit increase in career growth opportunity would influence employees' commitment in Nepalese commercial banks by a unit of 0.476. Similarly, it also implies a unit increase in use of existing skills would lead to a unit increase in employees' commitment in Nepalese commercial banks at a factor of 0.376 . The results further show that there is a significant relationship between employees' commitment in Nepalese commercial bank and the three variables of HRD (Training and development opportunity, Career growth opportunity and Use of existing skills), as shown by the $\mathrm{p}$ value; $(p<0.05)$. The equation $\mathrm{Y}=15.684+0.403 \mathrm{X} 1+0.476 \mathrm{X} 2+$ $0.376 \mathrm{X} 3$.

\section{Discussion and Conclusion}

The study intends to examine the contribution of human resource management practices on employees' commitment in Nepalese commercial banks. It is seen that majority male banking employees have higher academic qualifications as compared to female employees. It is also observed that the tendency to shift from one bank to another bank for higher posts after having a certain year of experience in one bank. Then, it is seen that significance of training and development opportunity, career development opportunity and utilization of existing abilities has positive relationship with workers' dedication in Nepalese commercial banks. Among the various factors of human resource development practices, career development opportunity has a solid connection with workers' commitment in Nepalese commercial banks. The research likewise found that human resource development practices i.e., training and advancement opportunity, career growth opportunity and utilization of existing abilities has fundamentally affected employees' dedication, which is reliable with the discoveries of Kareem and Hussein (2019) who showed that HRD 
methodologies are altogether identified with worker performance through the upgraded employees' commitment for organizational dedication. Further, Adresi and Darun (2017) additionally highlighted the concern of workers' towards their job security and dynamic workplace. Workers with the assistance of the firm's help will actually want to add to upgrade organizational dedication. This research additionally demonstrated that human resource development practices through various situational training and advancement programs, legitimate support and use of existing abilities of workers' and sufficient chance for career development affect on employees' responsibility in Nepalese commercial banks. This statement is also supported by the study of Razzaq et al. (2017) who showed that a human resource development practice has a positive and statistically significant impact on employees' commitment in the telecom sector of Pakistan. Similarly, Gellatly et al. (2009) suggested that organizations can use human resource development practices strategically to help shape the nature of overall employee commitment.

This study justifies the importance of human resource development practices in the employee development program. It is a powerful tool to make employees more committed towards their working institutions through realizing the potentiality and competencies of employees. Accordingly, the information produced through this study can be valuable to future researchers and concerned experts as well as authorities for their future concerned HRD methodologies. This study will be important to banking organizations in giving a premise for re-evaluating their Human resource development programs according to the evolving circumstance, specialists and academicians. The heads of banks may utilize the discoveries of the investigation in updating their HRD programs. Additionally, academicians will likewise discover the research valuable when adding to the current literature on human resource development practices. Still, the study presumes that there is as yet a considerable region for additional exploration and further improvements in this topic. Also, the research has attempted to evaluate and analyze the contribution of human human resource development practices in employees' commitment in Nepalese business banks.

\section{References}

[1]. Adresi A. A. \& Darun, M. R. (2017).

Determining relationship between strategic human resource management practices and organizational commitment, International Journal of Engineering Business Management, 9, 1-9. Retrieved from:

https://journals.sagepub.com/doi/full/10.1 177/1847979017731669

[2]. AlEmadi, M.A.S. (2006), "Relationship between employees ${ }^{\text {ee }}$ beliefs regarding training benefits and employees ${ }^{\text {ee }}$ organizational commitment in a petroleum company in the State of Qatar", $\mathrm{PhD}$ dissertation, George Washington University, District of Columbia, November 5.

[3]. Aranya, N. \& Jacobson, D. (1975). An Empirical Study of the Theories ofOrganizational and Occupational Commitment. Journal of Social Psychology, 97, 15-22.

[4]. Armstrong, M. (2014). Strategic human resource management. London: Kogan Page

[5]. Asfaw, A.M., Argaw, M.D., \&Bayissa, L. (2015). The Impact of Training and Development on Employee Performance and Effectiveness: A Case Study of District Five Administration Office, Bole Sub-City, Addis Ababa, Ethiopia. Journal of Human Resource and Sustainability Studies, 3(4), 188-202. doi: 10.4236/jhrss.2015.34025.

[6]. Becker, H. (1960). Notes on the Concept of Commitment. American Journal of 
Sociology, [online] 66(1), pp.32-40.

Available

at:

https://student.cc.uoc.gr/uploadFiles/111

0\%CE\%91010\%CE\%9A/BECKER2_AR

TISTIC\%20WORK.

[7]. Dayal, I. (1989). IHRD in Indian Organizations, "Current Perspectives and Future Issues". Vikalpa, Vol.14.

[8]. Dayal, Ishwar: HRD in Indian Organisations, "Current Perspectives and Future Issues". Vikalpa, Vol.14, OctoberDecember $\quad 1989, \quad$ P. $\quad 9-15$ IshwarDayal, Designing HRD Systems, New Delhi, Concept, 1993

[9]. De Ruyter, K., Moorman, L. and Lemmin, K. J. (2001). Antecedents of commitment and trust in customer- supplier relationships in high technology markets. Industrial MarketingManagement, 30, 271-286.

[10]. Deloitte. (2017). Employee engagement reimagined for higher education [online]. https://www2.deloitte.com/content/dam/ Deloitte/us/Documents/humancapital/ushc-employee-engagementreimagined-higher-education.pdf

[11]. Ferris, K. \&Aranya, N. (1983). “A Comparison of Two Organizational CommitmentScales." Personnel Psychology 36: pp.87-98.

[12]. Frederick, A. K. (2014). Assessing talent management as a tool for employee retention: A case study of Pro Credit Saving and Loans Limited Kumasi. University of Science and Technology.

[13]. Garavan, T. (2007). A strategic perspective on human resource development. Advancesin Developing Human Resources, 9(1), 11-30. doi: $10.1177 / 1523422306294492$

[14]. Gautam, "Strategic integration of HRM for organizational performance: Nepalese reality", South Asian Journal of
GlobalBusiness Research., Vol. 4 Issue: 1, pp.110-128, 2015.

[15]. Gellatlya, I. R., Huntera, K. H., Curriea, L. G. \& Irvin, P. G. (2009). HRM practices and organizational commitment profiles, The International Journal of Human Resource Management, 20 (4), 869-884. Retrieved from: https://www.researchgate.net/publication/ 200824264_HRM_practices_and_organi zational_commitment_profiles

[16]. Gounaris, S. P. (2005). Trust and commitment influence on customer retention: insights from business- tobusiness services. Journal of Business Research, 58, 126-140.

[17]. Hall, D.T. (1976). Careers in Organizations, CA: Goodyear, Santa Monica.

[18]. Jonker, J., \&Pennink, B. (2009). The Essence of ResearchMethodology. A Concise Guide for Master and PhD Students in Management Science. London UK: Springer Publication.

[19]. Kareem, M. A. \& Hussein, I. J. (2019). The Impact of Human Resource Development on Employee Performance and Organizational Effectiveness, Management Dynamics in the Knowledge Economy, 7. Retrieved from: https://www.researchgate.net/publication/ 336150142 The Impact of Human_Res ource_Development_on_Employee_Perf ormance_and_Organizational_Effectiven $\underline{\text { ess }}$

[20]. Khan, N. (2013). Human resource policies and practices in hospitality industry in India: A case study of selected hotels (Doctoral dissertation). Aligarh Muslim University.

[21]. McLagan, P., \&Suhadolnik, D. (1989). Models for HRD practice: the research report. 
Alexandria, VA: American Society for Training and Development.

[22]. Meyer, J. and Allen, N. (1991). A threecomponent conceptualization of organizational commitment. Human Resource Management Review, 1(1), pp.61-89

[23]. Meyer, J. P., \&Herscovitch, L. (2001). Commitment in the workplace: Toward a general model. Human Resource Management Review, 11, 299-326

[24]. Meyer, J., \& Allen, N. (1988). Links between Work Experience andOrganizational Commitment: A Longitudinal Analysis. Journal ofOccupational Psychology, 61, 195- 209

[25]. Mittal, S. (2013). HRD Climate in Public \& Private Sector Banks. Indian Journal of Industrial Relations, 49(1), 123-131.

[26]. Nadler, L. (1969). The Variety of Training Roles. Industrial and Commercial Training,

1(1), 34 .

[27]. NRB (2020). List of Banks and Financial Institutions, Statistics Division.

[28]. Nunnally, J. C., \& Bernstein, I. H. (1994). Psychometrictheory. New York, NY: McGraw-Hill.

[29]. Parasuraman, S. \&Alutto, J. (1984). "Sources of Outcome Stress in OrganizationalSettings: Toward the Development of a Structural Model.", Academy ofManagement Journal 27: pp.330-350.

[30]. Poon, June. (2004). Career commitment and career success: Moderating role of emotion perception. Career Development International. $\quad 9$. 374-390. 10.1108/13620430410544337.

[31]. Porter, L., Steers, R., Mowday, R., \&Boulian, $P$. (1974). OrganizationalCommitment, Job Satisfaction, and Turnover among
PsychiatricTechnicians. Journal of Applied Psychology, 59(5), 603-609

[32]. Potnuru, R.K.G., \& Sahoo, R.K. (2016). HRD interventions, employee competencies and organizational effectiveness: an empirical study. European Journal of Training and Development, 40(5), 345-365. doi: 10.1108/EJTD-02-2016-0008.

[33]. Razzaq, S., Aslam, U., Bagh, T. \& Saddique, S. (2017). The Impact of Human Resources Management Practices on Employee Commitment: Evidence from Pakistan Telecom Sector, International Journal of Academic Research in Business and Social Sciences, 7(7). Retrieved from: https://www.researchgate.net/publication/ 319469805_The_Impact_of_Human_Res ources_Management_Practices_on_Empl oyee_Commitment_Evidence_from_Paki stan_Telecom_Sector

[34]. Redman, T. and Wilkinson A. (2006). Contemporary Human Resource Management -Text and Cases. 2nd edition. UK: Prentice Hall, Financial Times

[35]. S. E. Khilji, "SAJGBR on the move: contributions, context and quality", South Asian Journal of Global BusinessResearch., Vol. 2 No. 2, pp. 156164, 2013.

[36]. Schwartzman, H. B. (1993). Ethnography in Organizations (Qualitative Research Methods) 1st Edition. London, UK: ASage University Publication.

[37]. Solomon, E.E., Bishop, R.C. \& Dresser, R.K. (1986). Organization moderatorsof gender differences in career development: A facet classification.Journal of Vocational Behavior, 29(1), 27-41.

[38]. Stevens, J., Beyer, J. \& Trice, H. (1978). "Assessing Personal, Role, and Organizational 
Predictors of Managerial Commitment." Academy of Management Journal 21: pp.380-396.

[39]. Swanson, A. R. and Elwood, F. Hilton III (2009). Foundation of Human Resource Development. 2nd edition. USA: BerrettKoehler Publishers Inc.

[40]. Swanson, R.A. (2001), "Human resource development and its underlying theory", Human

Resource Development International, Vol. 4 No. 3, pp. 299-312 